\title{
SINTESIS DAN KARAKTERISASI KOMPOSIT KARET ALAM/SELULOSA DENGAN VARIASI JENIS SELULOSA
}

\author{
Synthesize and Characterization of Natural Rubber/Cellulose Composite with \\ Variation of Cellulose Type
}

\author{
Hani HANDAYANI ${ }^{1 *}$, Adi CIFRIADI ${ }^{1}$, Aniek S. HANDAYANI ${ }^{2}$, Mochammad CHALID $^{3}$, \\ Riana HERLINA ${ }^{2}$, dan Shirley SAVETLANA ${ }^{4}$ \\ ${ }^{1}$ Pusat Penelitian Karet \\ Jalan Salak Nomor 1 Bogor 16151 Jawa Barat \\ *Email: hani.ppkbogor@gmail.com \\ ${ }^{2}$ Institut Teknologi Nasional \\ Jalan Raya Puspiptek Setu - Tangerang Selatan 15320 Banten \\ ${ }^{3}$ Universitas Indonesia \\ Kampus UI Depok 16424 Jawa Barat \\ 4) Universitas Lampung \\ Jalan Prof. Dr. Sumantri Brojonegoro No. 1 Bandar Lampung 35145 Lampung
}

Diterima : 13 September 2018 / Disetujui : 26 Oktober 2018

\begin{abstract}
Natural rubber and cellulose are two materials with very different compatibility. Natural rubber is nonpolar while cellulose is polar. The combination of natural rubber with cellulose expected produce composite with higher strength. The reinforcement concept of polymeric materials, such as natural rubber with cellulose as filler, result from increased rubber-fillerinteractions. The aim of this study was to determine the effect of several types of cellulose on the physical properties of the composite. About three types of cellulose used in this study were cellulose powder, cellulose onggok, and CMC (Carboxy Methyl Cellulose). Cellulose material is mixed in - two-roll mill together with natural rubber and other chemicals using two types of coupling agents, hexamine/resorcinol and maleic anhydride. The results showed that CMC showed better physical properties compared to two other types of cellulose, especially in tensile strength, compression set, and rebound resilience of the composite. Meanwhile, hexamine/resorcinol is more compatible to be used as coupling agent than maleic anhydride.
\end{abstract}

Keywords: cellulose; compatibility; composite; coupling agent; natural rubber

\section{Abstrak}

Karet alam dan selulosa merupakan dua material yang memiliki kompatibilitas yang sangat berbeda. Karet alam bersifat nonpolar sedangkan selulosa bersifat polar. Kombinasi antara karet alam dengan selulosa diharapkan akan menjadi komposit dengan kekuatan yang lebih tinggi. Konsep penguatan bahan polimer, seperti karet alam dengan bahan pengisi selulosa, terjadi akibat peningkatan interaksi karet-bahan pengisi. Penelitian ini bertujuan untuk mengetahui pengaruh beberapa jenis selulosa terhadap sifat fisik komposit yang dihasilkannya. Sebanyak tiga jenis selulosa digunakan dalam penelitian ini yaitu serbuk selulosa dari tandan kosong kelapa sawit, selulosa onggok dari limbah pati singkong, dan CMC (Carboxy Methyl Cellulose). Bahan selulosa digiling dalam mesin giling terbuka bersama dengan karet alam dan bahanbahan lainnya menggunakan dua jenis bahan penyambung (coupling agent) yaitu hexamine/resorcinol dan anhidrida maleat. Hasil penelitian menunjukkan bahwa CMC memberikan hasil sifat fisik yang relatif lebih baik dibandingkan dengan dua jenis selulosa lainnya terutama dalam hal kuat tarik, pampatan tetap, dan ketahanan pantul komposit yang dihasilkannya. Sementara itu hexamine/ resorcinol lebih 
kompatibel digunakan sebagai bahan penyambung dibandingkan anhidrida maleat.

Kata kunci: bahan penyambung; karet alam; kompatibilitas; komposit; selulosa

\section{PENDAHULUAN}

Kemajuan zaman dan perkembangan teknologi menyebabkan pengetahuan dan penemuan berbagai material baru dengan sifat dan karakter yang unik semakin berkembang. Kebanyakan teknologi modern memerlukan bahan dengan kombinasi sifatsifat luar biasa yang tidak dapat dicapai oleh bahan-bahan lazim seperti logam, keramik, dan bahan polimer. Salah satu material yang banyak dikembangkan adalah material komposit. Komposit adalah material yang tersusun atas campuran dua atau lebih material dengan sifat kimia dan fisika berbeda, dan menghasilkan sebuah material baru yang memiliki sifat berbeda dengan material penyusunnya.

Salah satu contoh paling mudah dari material komposit adalah beton cor yang merupakan campuran dari pasir, batu koral, semen, besi, dan air. Masing-masing material penyusun dari beton cor memiliki sifat yang berbeda, namun ketika dicampurkan dengan perbandingan serta teknik tertentu ternyata menghasilkan beton yang sangat kuat, keras, dan tahan terhadap berbagai cuaca. Di dalam tubuh kita juga terdapat material komposit, yaitu tulang. Tulang yang menjadi kerangka dari tubuh kita terbuat dari dua bahan yang sangat berbeda secara sifat yaitu bahan yang keras tetapi rapuh yang disebut hydroxyapatite (terutama kalsium fosfat) dan bahan yang lembut dan fleksibel yang disebut kolagen (protein). Bahan kolagen ketika bergabung dengan hydroxyapatite menjadikan tulang memiliki sifat-sifat yang diperlukan untuk mendukung tubuh.

Material komposit tersusun atas dua tipe material penyusun yakni matriks dan fiber (reinforcement). Keduanya memiliki fungsi yang berbeda, fiber berfungsi sebagai material rangka yang menyusun komposit, sedangkan matriks berfungsi untuk merekatkan fiber dan menjaganya agar tidak berubah posisi. Campuran keduanya akan menghasilkan material yang keras, kuat, namun ringan.

Karet alam dikenal dengan 1,4poliisoprena merupakan makromolekul alami yang memiliki sifat spesial yaitu elastis dan fleksibel, namun kuat tarik dan ketahanan sobek yang rendah merupakan kelemahan utama dari produk karet alam, terutama untuk produk sarung tangan medis dan kondom. Sementara itu selulosa adalah komponen utama dari dinding sel tumbuhan dan bahan bangunan dasar bagi banyak tekstil dan kertas. Selulosa tidak dapat dicerna oleh manusia, hanya dapat dicerna oleh hewan yang memiliki enzim selulase. Selulosa memiliki struktur kimia seperti pada starch, sehingga modifikasi selulosa dapat dilakukan untuk menggantikan peran starch sebagai bahan pengisi (Handayani et al., 2017; Chalid et al., 2014; Chalid et al., 2015). Perpaduan karet alam dengan bahan pengisi selulosa diharapkan dapat menjadi komposit dengan kekuatan yang lebih baik. Proses penguatan ini dilakukan sebab karet alam memiliki kuat tarik yang rendah yaitu sekitar $1,5 \mathrm{MPa}$ (Santulli et al., 2014).

Penelitian terhadap penggunaan berbagai jenis bahan pengisi karet sudah banyak dilakukan. Penelitian yang dilakukan oleh Santulli et al. (2014) terhadap variasi massa kitin sebagai pengisi karet alam menunjukkan bahwa komposisi $15 \%$ kitin memberi kuat tarik terbesar terhadap komposit dibandingkan dengan komposit dengan komposisi $0 \%$, 5\%, dan $10 \%$ kitin. Hasil SEM pada penelitian tersebut menunjukkan bahwa semakin banyak jumlah kitin, maka permukaan komposit akan menunjukkan fenomena deadhesi antara karet alam dan kitin. Bukit dan Frida (2013) juga melakukan variasi komposisi zeolit sebagai bahan pengisi dalam komposit karet alam/polipropilena. Hasil yang diperoleh adalah zeolit dengan massa 2\% memiliki kuat tarik dan perpanjangan putus yang lebih tinggi dibandingkan dengan zeolit dengan massa $4 \%$ dan $6 \%$.

Selama ini, bahan pengisi untuk kompon karet alam yang biasa digunakan adalah carbon black dan silika. Namun, bahan ini memiliki kelemahan, yaitu dari segi harga dan ketersediaan. Bahan-bahan ini berasal dari sumber yang tidak dapat 
diperbaharui dengan harga relatif mahal. Selain itu, silika juga memiliki kelemahan yaitu menghasilkan abu dalam jumlah banyak saat ban bekas dibuang dengan cara dibakar. Penggunaan selulosa sebagai bahan pengisi dapat mengatasi masalahmasalah tersebut sebab selulosa merupakan polimer alam yang cukup melimpah, mudah diperoleh, dapat diperbaharui dan mudah dibuang. Setiawati et al. (2015) telah mencoba membuat komposit karet alam/selulosa dari Tandan Kosong Kelapa Sawit (TKKS) dengan variasi massa selulosa $(0,5,10$, dan 15 bsk). Hasilnya menunjukkan bahwa karet alam/selulosa dengan jumlah selulosa 15 bsk memiliki nilai tegangan dan modulus Young tertinggi masing-masing sebesar $15,2 \times 107 \mathrm{~N} / \mathrm{m}^{2}$ dan $1,504 \times 107 \mathrm{~N} / \mathrm{m}^{2}$. Penelitian mengenai bahan pengisi selulosa dari jenis yang lain selain tandan kosong kelapa sawit perlu dilakukan mengingat jenis selulosa yang tersedia baik alami maupun sintetik sangat beragam dan memiliki karakteristik yang berbeda-beda.

Tujuan dari penelitian ini adalah mempelajari sifat dan karakteristik komposit karet alam/selulosa dari berbagai jenis selulosa. Melalui penelitian ini diharapkan diperoleh komposit karet alam/selulosa dengan kekuatan sobek yang cukup baik sehingga dapat dikembangkan untuk bahan baku pembuatan produk yang membutuhkan kekuatan sobek cukup tinggi seperti ban dalam sepeda motor dan sarung tangan.

\section{BAHAN DAN METODE}

Kegiatan penelitian ini dilaksanakan dari bulan Februari sampai Juli 2018. Pengolahan serbuk selulosa dari Tandan Kosong Kelapa Sawit (TKKS) dan selulosa onggok dari limbah pati singkong dilakukan di Laboratorium Teknik Kimia, Institut Teknologi Indonesia, Tangerang. Pembuatan komposit dan vulkanisat serta pengujiannya dilakukan di Pabrik Percobaan dan Laboratorium Penguji, Pusat Penelitian Karet, Bogor.

Bahan yang digunakan dalam penelitian ini meliputi karet SIR 20 yang diperoleh dari supplier lokal, serbuk kasar selulosa dari serat tandan kosong kelapa sawit $(B M=226.697,4 \mathrm{~g} / \mathrm{mol})$, selulosa onggok dari limbah pati singkong $(\mathrm{BM} \approx$ $243.000 \mathrm{~g} / \mathrm{mol}$ ), CMC dari supplier lokal $(\mathrm{BM}=264,204 \mathrm{~g} / \mathrm{mol})$, serta bahan kimia komponding karet kualitas teknis dari supplier lokal. Adapun bahan kimia komponding karet meliputi: sulfur, asam stearat, seng oksida, bahan penyambung hexamine (hexamethylenetetramine) / resorcinol (1,3-isomer dari benzenediol) dan anhidrida maleat, bahan pencepat CBS (cyclohexyl benzothiazole sulfenamide), a n tioksidan TM (trimethyl dihydroquinoline), serta bahan pelunak gliserol. Gambar untuk serbuk selulosa, selulosa onggok, dan CMC disajikan dalam Gambar 1.

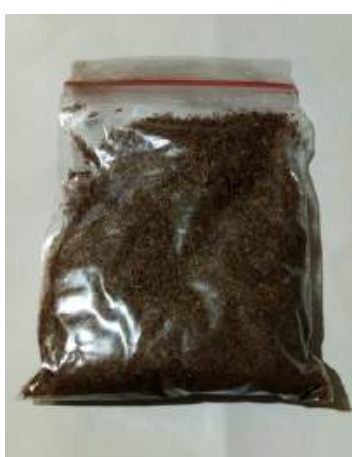

a

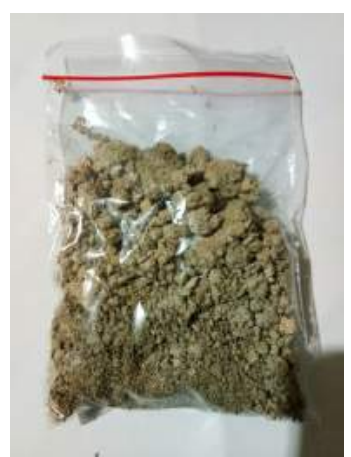

b

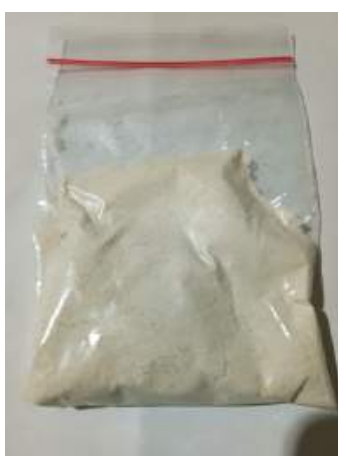

C

Gambar 1. Penampakan visual bahan selulosa yang digunakan (a) serbuk selulosa, (b) selulosa onggok, dan (c) CMC

Figure 1. Visual appearance of cellulose material used (a) cellulose powder, (b) cellulose onggok, and (c) CMC 
Peralatan penelitian meliputi peralatan untuk preparasi kompon berupa gilingan terbuka (open mill), Rheometer MDR 2000 untuk pengujian karakteristik pematangan, Tensometer untuk pengujian kuat tarik dan perpanjangan putus, Durometer Shore-A untuk pengujian kekerasan, alat uji kekuatan sobek, serta alat uji pampatan tetap.

Dalam penelitian ini digunakan tiga jenis selulosa yaitu serbuk selulosa dan selulosa onggok yang merupakan selulosa alam serta CMC yang merupakan selulosa sintetik. Serbuk selulosa diperoleh dari tandan kosong kelapa sawit (TKKS) yang digiling dan dihaluskan dengan crusher. Sedangkan selulosa onggok diperoleh dari limbah perasan pati singkong yang dikeringkan. Adapun CMC banyak dijual di pasaran. Selain itu dalam penelitian ini digunakan dua jenis bahan penyambung (coupling agent) yaitu hexamine/resorcinol dan anhidrida maleat. Komposit karet alam / selulosa dibuat dengan mencampurkan karet alam, selulosa, dan beberapa bahan kimia yang lain di dalam mesin giling terbuka kemudian dibuat vulkanisat dan diuji beberapa parameter sifat fisika, diantaranya kekerasan, kuat tarik, perpanjangan putus, kuat sobek, pampatan tetap, dan ketahanan pantul.

\section{Pembuatan Komposit Karet Alam /Selulosa}

Karet alam dan selulosa digiling dengan bahan-bahan lain di dalam open mill sesuai dengan resep kompon. Penambahan bahan-bahan kimia menggunakan satuan bsk (bagian per seratus karet), ini digunakan untuk perhitungan rumus dimana bahan kimia lainnya dihitung sebagai bagian per 100 berat polimer karet. Resep kompon dengan variasi 3 jenis selulosa dan 2 jenis bahan penyambung dapat dilihat pada Tabel 1. Sebagai kontrol, dibuat komposit karet alam/selulosa yang tidak menggunakan bahan penyambung. Kompon-kompon tersebut kemudian diamati karakteristik pematangannya dan diuji beberapa parameter sifat fisika.

Kesembilan kompon yang tertera pada Tabel 1 kemudian divulkanisasi hingga membentuk vulkanisat di dalam mesin press vulkanisasi pada suhu $150^{\circ} \mathrm{C}$ selama waktu tertentu sesuai dengan hasil Rheometernya yang diukur menggunakan alat Rheometer MDR 2000.

Tabel 1. Susunan formula komposit karet alam/selulosa dengan variasi jenis selulosa dan bahan penyambung

Table 1. Receipt of natural rubber/cellulose composite with varied kinds of cellulose and coupling agents

\begin{tabular}{|c|c|c|c|c|c|c|c|c|c|}
\hline \multirow{2}{*}{$\begin{array}{l}\text { Bahan } \\
\text { Materials }\end{array}$} & \multicolumn{9}{|c|}{$\begin{array}{c}\text { Jumlah ( bagian per seratus karet, bsk) } \\
\text { Dosage (per hundred rubber, phr) }\end{array}$} \\
\hline & A & B & $\mathrm{C}$ & $\mathrm{D}$ & $\mathrm{E}$ & $\mathrm{F}$ & $\mathrm{G}$ & $\mathrm{H}$ & $\mathrm{I}$ \\
\hline NR & 100 & 100 & 100 & 100 & 100 & 100 & 100 & 100 & 100 \\
\hline Serbuk selulosa & 25 & 25 & 25 & & & & & & \\
\hline Selulosa onggok & & & & 25 & 25 & 25 & & & \\
\hline $\mathrm{CMC}$ & & & & & & & 25 & 25 & 25 \\
\hline Hexamin & & 3 & & & 3 & & & 3 & \\
\hline Resorcinol & & 3 & & & 3 & & & 3 & \\
\hline Anhidrida maleat & & & 3 & & & 3 & & & 3 \\
\hline $\mathrm{ZnO}$ & 5 & 5 & 5 & 5 & 5 & 5 & 5 & 5 & 5 \\
\hline Asam stearat & 2 & 2 & 2 & 2 & 2 & 2 & 2 & 2 & 2 \\
\hline CBS & 1,4 & 1,4 & 1,4 & 1,4 & 1,4 & 1,4 & 1,4 & 1,4 & 1,4 \\
\hline TMQ & 1,5 & 1,5 & 1,5 & 1,5 & 1,5 & 1,5 & 1,5 & 1,5 & 1,5 \\
\hline Gliserol & 3 & 3 & 3 & 3 & 3 & 3 & 3 & 3 & 3 \\
\hline Sulfur & 1,7 & 1,7 & 1,7 & 1,7 & 1,7 & 1,7 & 1,7 & 1,7 & 1,7 \\
\hline
\end{tabular}




\section{Karakterisasi vulkanisat}

Vulkanisat yang terbentuk kemudian diuji beberapa parameter sifat fisik dan mekanik yang berpengaruh diantaranya kekerasan, kuat tarik, perpanjangan putus, kuat sobek, rebound resilience, dan pampatan tetap.

Pengujian kuat tarik dan perpanjangan putus dilakukan berdasarkan metode ASTM D 412 - 98a (ra 2002), pengujian kekerasan dilakukan berdasarkan metode ASTM D 2240, pengujian kekuatan sobek dilakukan berdasarkan metode ASTM D 624-00 (2012), pengujian rebound resilience dilakukan berdasarkan metode ISO 4662:2018, dan pengujian pampatan tetap dilakukan berdasarkan metode ISO 815:2008.

\section{HASIL DAN PEMBAHASAN}

\section{Karakteristik Pematangan Komposit Karet Alam/Selulosa dengan Variasi Jenis Selulosa dan Bahan Penyambung}

Tabel 2 menyajikan data karakteristik pematangan komposit karet alam/selulosa dengan variasi jenis selulosa dan bahan penyambung menggunakan alat Rheometer MDR 2000. Dari tabel terlihat komposit C dan $\mathrm{F}$ tidak dapat ditentukan karakteristik pematangannya sehingga komposit tersebut tidak dapat dibentuk menjadi vulkanisat dan diuji sifat fisikanya. Sedangkan komposit $\mathrm{H}$ dan I tidak dapat ditentukan waktu scorchnya $\left(\mathrm{ts}_{2}\right)$ karena terlalu pendek.
Komposit C dan F menggunakan selulosa yang berbeda tetapi bahan penyambungnya sama yaitu anhidrida maleat. Data tersebut menunjukkan bahwa anhidrida maleat kurang kompatibel untuk digunakan sebagai bahan penyambung (coupling agent) pada komposit karet alam/selulosa terutama untuk jenis selulosa dari alam seperti serbuk selulosa dan selulosa onggok. Sedangkan untuk selulosa sintetik seperti CMC, anhidrida maleat dapat kompatibel digunakan sebagai bahan penyambung (coupling agent) namun data Rheometer ini harus didukung dengan data sifat fisika dari vulkanisat yang dihasilkannya. Data sifat fisika vulkanisat disajikan pada Tabel 3.

Secara visual, homogenitas komposit dapat dilihat dari permukaan kompon setelah digiling di dalam mesin giling terbuka (two-roll open mill) seperti yang ditunjukkan pada Gambar 2. Gambar 2 menyajikan hasil giling untuk komposit dari selulosa serbuk menggunakan bahan penyambung hexamine/resorcinol (a) dan anhidrida maleat (b). Dari gambar dapat dilihat bahwa hasil gilingan (a) secara visual relatif lebih homogen dan permukaannya lebih halus dibandingkan dengan (b). Hasil yang sama juga diberikan untuk komposit karet alam/selulosa yang menggunakan selulosa onggok dan CMC. Hasil gilingan komposit yang menggunakan anhidrida maleat sebagai bahan penyambung relatif kasar dan kurang homogen dibandingkan $\mathrm{d}$ e $\mathrm{ng} \mathrm{a} \mathrm{n}$ y a $\mathrm{ng}$ m e $\mathrm{ng} \mathrm{gu}$ a $\mathrm{kan}$ hexamine/resorcinol sebagai bahan penyambung.

Tabel 2. Karakteristik pematangan komposit dengan variasi selulosa dan bahan penyambung

Table 2. Characteristic for vulcanization of composite with varied of cellulose and coupling agents

\begin{tabular}{lccccccccc}
\hline $\begin{array}{l}\text { Rheometer Kompon } \\
\text { Compound Rheometer }\end{array}$ & A & B & C & D & E & F & G & H & I \\
\hline Smax-Smin & 2,08 & 2,12 & NA & 2,02 & 2,19 & NA & 2,17 & 1,98 & 1,12 \\
Smax & 2,27 & 2,37 & NA & 2,13 & 2,34 & NA & 2,26 & 2,14 & 1,31 \\
Smin & 0,19 & 0,25 & NA & 0,11 & 0,15 & NA & 0,09 & 0,16 & 0,19 \\
$T_{90}$ & 5,22 & 7,08 & NA & 10,53 & 7,36 & NA & 11,58 & 8,1 & 19,58 \\
$\mathrm{TS}_{2}$ & 6,09 & 8,27 & NA & 15,27 & 7,59 & NA & 12,31 & NA & NA \\
\hline
\end{tabular}




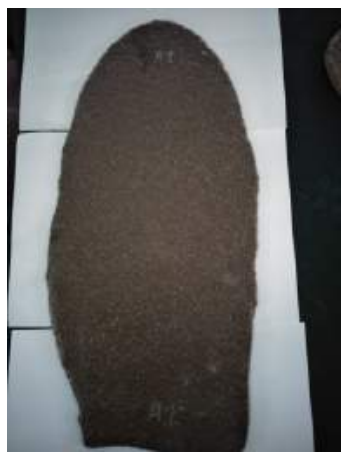

a

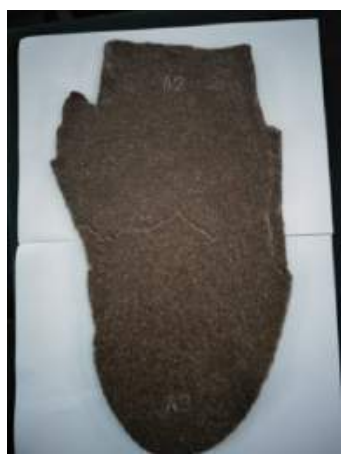

b

Gambar 2. Hasil giling komposit karet alam/selulosa dari jenis selulosa serbuk dengan bahan penyambung (a) hexamine/resorcinol dan (b) anhidrida maleat

Figure 2. Result of natural rubber/cellulose composite mixing from cellulose powder with coupling agent (a) hexamine/ resorcinol and (b) maleic anhydride

\section{Karakteristik Sifat Fisik Komposit Karet Alam/Selulosa Dengan Variasi Jenis Selulosa}

Penambahan selulosa sebagai bahan pengisi untuk komposit karet alam/selulosa berpengaruh terhadap sifat fisik dan mekanik dari kompositnya. Hasil pengujian sifat fisik untuk kesembilan vulkanisat dapat dilihat pada Tabel 3.

\section{Pengaruh terhadap kekerasan (hardness)}

Pengaruh selulosa terhadap tingkat kekerasan pada komposit karet alam/selulosa dapat dilihat pada Tabel 3. Penambahan selulosa sebagai bahan pengisi cenderung meningkatkan kekerasan sebesar 5-7 satuan Shore A (kekerasan awal karet alam 40 Shore A). Kenaikan tingkat kekerasan dapat disebabkan karena penambahan selulosa menjadikan komposit

Tabel 3. Sifat fisika komposit karet alam/selulosa dengan variasi jenis selulosa dan bahan penyambung

Table 3. Physical properties of natural rubber/cellulose composite with varied kinds of cellulose and coupling agent

\begin{tabular}{|c|c|c|c|c|c|c|c|}
\hline \multirow{2}{*}{$\begin{array}{c}\text { Sifat Fisika } \\
\text { Physical Properties }\end{array}$} & \multicolumn{7}{|c|}{$\begin{array}{l}\text { Vulkanisat } \\
\text { Vulcanized }\end{array}$} \\
\hline & A & B & $\mathrm{D}$ & $\mathrm{E}$ & G & $\mathrm{H}$ & I \\
\hline Kekerasan (Shore A) & 47 & 55 & 45 & 53 & 40 & 45 & 31 \\
\hline Kuat tarik $(\mathrm{MPa})$ & 6,5 & 7,5 & 6,9 & 8 & 10,1 & 11,2 & 3,3 \\
\hline Perpanjangan putus (\%) & 720 & 570 & 670 & 520 & 700 & 600 & 780 \\
\hline Kuat sobek $(\mathrm{MPa})$ & 20,7 & 24 & 21,2 & 30,1 & 20,4 & 25,4 & 13,5 \\
\hline Pampatan tetap, $\%$ suhu $27 \pm 2{ }^{\circ} \mathrm{C}$ & 16,95 & 14,38 & 17,36 & 18,07 & 14,13 & 13,69 & 35,24 \\
\hline Pampatan tetap, $\%$ suhu $-5 \pm 2{ }^{\circ} \mathrm{C}$ & 6,36 & 7,33 & 7,82 & 5,45 & 7 & 4,38 & 16,3 \\
\hline Ketahanan pantul (\%) & 65 & 69,5 & 67 & 71,5 & 64,5 & 68,5 & 61 \\
\hline
\end{tabular}

Keterangan:

Komposit $\mathrm{C}$ dan $\mathrm{F}$ tidak diperoleh data karena komposit tersebut tidak dapat dicetak sehingga tidak dapat dilakukan pengujian sifat fisik kompositnya 
lebih berisi dimana selulosa mengisi bagianbagian kosong dari struktur komposit akibatnya komposit menjadi lebih keras. Semakin banyak selulosa yang ditambahkan, kompon semakin rapat dan padat sehingga kompon semakin keras (Handayani et al., 2018). Penambahan bahan penyambung hexamine/resorcinol kembali meningkatkan kekerasan komposit karet alam/selulosa sebanyak 5-8 satuan Shore A. Hal ini dapat disebabkan karena bahan penyambung meningkatkan interaksi intramolekuler antara karet alam-selulosa sehingga struktur komposit menjadi lebih rapat dan padat akibatnya kekerasan komposit meningkat.

Hasil terbalik ditunjukkan oleh komposit I yang menggunakan CMC dan bahan penyambung anhidrida maleat, kekerasannya justru menurun cukup tajam sekitar 9 satuan Shore A. Diduga penambahan anhidrida maleat ke dalam komposit karet alam/CMC tidak berperan sebagai bahan penyambung tetapi anhidrida maleat berperan seperti bahan pelunak untuk melunakkan karet alam akibatnya kekerasan komposit karet alam/CMC menurun. Hal ini juga yang menyebabkan karet alam dan selulosa tidak dapat bercampur dengan baik meskipun sudah menggunakan anhidrida maleat yang biasanya digunakan sebagai coupling agent (bahan penyambung).

\section{Pengaruh terhadap kuat tarik (tensile strength)}

Pengaruh selulosa terhadap kuat tarik pada komposit karet alam/selulosa dapat dilihat pada Tabel 3. Komposit dengan menggunakan CMC memberikan hasil kuat tarik yang lebih baik (mencapai lebih dari 10 $\mathrm{MPa}$ ) dibandingkan selulosa lainnya. Penggunaan bahan penyambung hexamine/resorcinol cenderung meningkatkan kuat tarik 1-2 MPa pada semua jenis selulosa. Kenaikan kuat tarik dapat disebabkan penambahan selulosa memperkuat interaksi karet-selulosa, sehingga meningkatkan elastisitas komposit karet alam/selulosa (Handayani dkk., 2018).
Hasil terbalik ditunjukkan oleh komposit I yang menggunakan CMC dan bahan penyambung anhidrida maleat, kuat tariknya justru menurun cukup tajam sekitar $7 \mathrm{MPa}$. Hal ini dapat disebabkan karena anhidrida maleat merupakan bahan penyambung yang kurang baik untuk komposit karet alam/selulosa sehingga penambahan bahan tersebut justru melemahkan interaksi karet alam-selulosa sehingga elastisitas komposit karet alam/selulosa menurun.

\section{Pengaruh terhadap perpanjangan putus (elongation at break)}

Pengaruh selulosa terhadap perpanjangan putus pada komposit karet alam/selulosa dapat dilihat pada Tabel 3 . Komposit dengan menggunakan serbuk selulosa memberikan hasil perpanjangan putus yang lebih baik dibandingkan selulosa lainnya. Penggunaan bahan penyambung hexamine/resorcinol cenderung menurunkan perpanjangan putus 100$150 \%$ pada semua jenis selulosa. Penurunan perpanjangan putus dapat disebabkan karena peran bahan penyambung untuk meningkatkan interaksi karet-selulosa berakibat pada menurunnya interaksi intermolekular karet alam sehingga elastisitas karet alam menurun akibatnya komposit menjadi lebih mudah putus dibandingkan komposit yang tidak menggunakan bahan penyambung.

Hal sebaliknya terjadi pada komposit I yang menggunakan CMC dan bahan penyambung anhidrida maleat justru perpanjangan putusnya meningkat. Dalam hal ini anhidrida maleat merupakan bahan penyambung yang kurang baik untuk komposit karet alam/selulosa sehingga tidak dapat meningkatkan interaksi antara karet alam dengan selulosa. Akan tetapi anhidrida maleat lebih kompatibel dengan selulosa sehingga penambahan anhidrida maleat justru meningkatkan interaksi intermolekular karet alam, akibatnya elastisitas karet alam meningkat sehingga komposit menjadi lebih kuat dan lebih sulit putus. 


\section{Pengaruh terhadap kuat sobek (tear strength)}

Pengaruh selulosa terhadap kuat sobek pada komposit karet alam/selulosa dapat dilihat pada Tabel 3. Komposit dengan menggunakan selulosa onggok memberikan hasil kuat sobek yang lebih baik dibandingkan selulosa lainnya. Semakin besar nilai kuat sobek menunjukkan bahwa komposit semakin kuat. Semakin rendah nilai kuat sobek berarti kekuatan komposit semakin menurun. Penggunaan bahan penyambung hexamine/ resorcinol cenderung meningkatkan kekuatan sobek 3$9 \mathrm{MPa}$ pada semua jenis selulosa. Kenaikan kekuatan sobek dapat disebabkan karena penambahan bahan penyambung memperkuat interaksi karet-selulosa, sehingga meningkatkan kekuatan komposit karet alam/selulosa.

Hasil terbalik ditunjukkan oleh komposit I yang menggunakan CMC dan bahan penyambung anhidrida maleat, kuat sobeknya justru menurun cukup tajam sekitar $7 \mathrm{MPa}$. Hal ini dapat disebabkan karena anhidrida maleat merupakan bahan penyambung yang kurang baik untuk komposit karet alam/selulosa sehingga penambahan bahan tersebut justru melemahkan interaksi karet alam-selulosa sehingga kekuatan komposit karet alam/ selulosa menurun.

\section{Pengaruh terhadap pampatan tetap (compression set)}

Pengaruh selulosa terhadap pampatan tetap pada komposit karet alam/selulosa dapat dilihat pada Tabel 3. Pampatan tetap diuji pada 2 suhu, yaitu suhu $27 \pm 2{ }^{\circ} \mathrm{C}$ dan $5 \pm 2{ }^{\circ} \mathrm{C}$ selama 72 jam. Komposit dengan menggunakan CMC memberikan hasil pampatan tetap yang lebih baik dibandingkan selulosa lainnya. Semakin besar nilai pampatan tetap menunjukkan bahwa setelah dipampatkan elastisitas karet semakin berkurang (Handayani, Faturrohman, \& Kuncoro, 2011). Semakin rendah nilai pampatan tetap berarti ketahanan elastisitas karet semakin baik.

Penggunaan bahan penyambung hexamine/ resorcinol memberikan pengaruh yang berbeda tergantung dari selulosa yang digunakan. Hal ini berkaitan dengan interaksi intermolekuler (selulosa-selulosa) dari masing-masing selulosa. Semakin kuat interaksi selulosa-selulosa dari selulosa yang digunakan menyebabkan interaksi karet-selulosa semakin berkurang (Ulfah et al., 2015; Ma et al., 2013). Perbedaan nilai pampatan tetap yang drastis terlihat pada komposit I yang menggunakan CMC dan bahan penyambung anhidrida maleat. Nilai pampatan tetap komposit I jauh lebih tinggi dibandingkan komposit lainnya. Hal ini menunjukkan bahwa interaksi intermolekuler CMC lebih kuat dibandingkan interaksi karet alam-CMC sehingga ketika komposit dipampatkan dengan tekanan dari suatu beban pada suhu dan waktu tertentu terjadi perubahan yang cukup besar terhadap elastisitasnya.

\section{Pengaruh terhadap ketahanan pantul (rebound resilience)}

Pengaruh selulosa terhadap ketahanan pantul pada komposit karet alam/selulosa dapat dilihat pada Tabel 3 . Komposit dengan menggunakan CMC memberikan hasil ketahanan pantul yang lebih baik dibandingkan selulosa lainnya. Semakin besar nilai ketahanan pantul menunjukkan bahwa ketahanan komposit terhadap benturan semakin rendah. Semakin rendah nilai ketahanan pantul menunjukkan bahwa komposit semakin tahan terhadap benturan. Penggunaan hexamine/resorcinol sebagai bahan penyambung meningkatkan nilai ketahanan pantul komposit karet alam/selulosa sebanyak 4-5\%. Sedangkan anhidrida maleat justru menurunkan nilai ketahanan pantul komposit karet alam/selulosa. Hal ini dapat disebabkan karena penambahan anhidrida maleat meningkatkan interaksi intermolekuler karet alam sehingga elastisitas komposit lebih baik dibandingkan dengan komposit lainnya.

\section{KESIMPULAN}

Berdasarkan hasil penelitian yang dilakukan, dapat disimpulkan bahwa jenis selulosa dan bahan penyambung berpengaruh terhadap sifat fisika komposit karet alam/selulosa. CMC memberikan hasil sifat fisik yang relatif lebih baik 
dibandingkan dengan dua jenis selulosa lainnya terutama dalam hal kuat tarik, pampatan tetap, dan ketahanan pantul komposit yang dihasilkannya. Sementara itu hexamine/resorcinol lebih kompatibel digunakan sebagai bahan penyambung dibandingkan anhidrida maleat.

\section{UCAPAN TERIMA KASIH}

Ucapan terima kasih disampaikan kepada Kemenristekdikti atas bantuan dana penelitian melalui program Penelitian Strategis Nasional Konsorsium Tahun Anggaran 2018 dengan nomor kontrak: 34/ KP/LPKT-ITI/III/2018. Terima kasih dan penghargaan turut disampaikan kepada Institut Teknologi Nasional selaku penerima hibah, serta Universitas Indonesia dan Universitas Lampung selaku mitra konsorsium.

\section{DAFTAR PUSTAKA}

Bukit, N., \& Frida, E. (2013). The Effect zeolite addition in natural rubber polypropylene composite on mechanical, structure, and thermal characteristics. Makara Journal of Technology, 17(3), 113-120. Doi : 10.7454/mst.v17i3.2926

Chalid, M., Handayani, A.S., \& Budianto, E. (2014). Functionalization of starch for macro-initiator of atomic transfer radical polymerization (ATRP). Advanced Materials Research, 1051, 90-94. Doi: 10.4028/www.scientific. net/AMR. 1051.90 .

Chalid, M., Yuanita, E., \& Pratama, J. (2015). Study of alkalization to the crystallinity and the thermal behavior of arenga pinnata "ijuk" fibers-based polylactic acid (PLA) biocomposite. Materials Science Forum, 827, 326-331. Doi : 10.4028/www.scientific.net/MSF.827 .326 .
Handayani, A.S., Chalid, M., Budianto, E., \& Priadi, D. (2017). Grafting of amylopectin with various alkyl methacrylate by atom transfer radical polymerization for engineering application. Macromolecular Symposia, 371(1), 58-60. Doi : 10.1002/masy. 201600038.

Handayani, H., Fathurrohman, M.I., \& Kuncoro, I. (2011). Karakteristik sifat fisik dan ketahanan terhadap minyak dari karet alam epoksi. Jurnal Penelitian Karet, 29(1), 49-62. Doi : 10.22302/ppk.jpk.v29i1.111.

Handayani, H., Fathurrohman, M.I., Prastanto, H., Ramadhan, A., \& Kinasih, N.A. (2018). Sifat mekanik rubber seal katup tabung gas LPG pada variasi ukuran dan dosis silika. Jurnal Penelitian Karet, 36(1), 77-88. Doi : 10.22302/ppk.jpk.v36i1.435.

Ma, J.H., Zhao, S.H., Zhang, L.Q., \& Wu, Y.P. (2013). Comparison of structure and properties of two styrene-butadiene rubbers filled with carbon black, carbon-silica dual-phase filler, and silica. Rubber Chemistry and

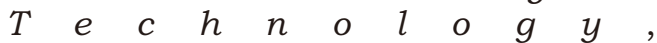
86 (4), 664-678. Doi : 10.5254/rct.13. 87956.

Ulfah, I.M., Fidyaningsih, R., Rahayu, S., Fitriani, D.A., Saputra, D.A., Winarto, D.A., \& Wisojodharmo, L.A. (2015). Influence of carbon black and silica filler on the rheological and mechanical properties of natural rubber compound. Procedia Chemistry, 16, 258-264. Doi : 10.1016/j.proche.2015. 12.053. 
Santulli, C., Puglia, D., Rallini, M., Visakh, P.M., Kenny, J.M., \& Thomas, S. (2014). Natural rubber composites filled with a low volume of crab chitin whiskers: mechanical and thermal characterization. Malaysian Polymer Journal, 9(1), 18-23.
Setiawati, S., Sitorus, B., \& Malino, M.B. (2015). Sintesis dan karakterisasi komposit karet alam-selulosa dari tandan kosong kelapa sawit dengan va 